DEUÍFD Türk Kültürünü Mayalayanlar Özel Sayısı / 2021, ss. 717-737.

\title{
TÜKETİCİ HAKLARI VE ESNAF DENETİMİ -HUKUK TARİHİMİZDEN ÖRNEKLER-*
}

Hadi SOFUOĞLU**

\section{ÖZ}

Tarih boyunca toplumların ticaret hayatında tüketicinin korunması meselesi, güncelliğini hiçbir zaman kaybetmemiş bir konudur. $\mathrm{Bu}$ süreçte tüketiciyi korumak için geliştirilen yöntemlerin başında hiç kuşkusuz üretimde standardizasyonun ve kalitenin sağlanması, ölçü ve tartı kontrolü, çarşı ve pazarların düzenlenmesi ve denetlenmesi yer almaktadır. İslâm hukuku kaynakları açısından baktığımızda, tüketicilerin aldatılmaması ve haklarının korunması için muhayyerlik müessesesinin geliştirildiğini görüyoruz. İslam'ın ilk dönemlerinden beri kusurlu mal ve hizmetlere karşı tüketicilerin korunmasina yönelik birtakım tedbirler alınmış ve tüketicilere böyle bir durumla karşı karşıya kaldıklarında akdi bozma hakkı tanınmıştır. Alıcı ve satıcı arasındaki ihtilafları çözmek, hakları teminat altına almak, mal ve hizmet standardını korumak için Hz. Peygamber'den bugüne kadar bir takım kurum ve kuruluşlar da bulunmaktadir.

İşte bu tebliğde İslam tarihi boyunca tüketici ve tüketici hakları ile ilgili ortaya konmuş hukuki tedbirlerden, özellikle Osmanlı uygulamasında karșımıza çıkan esnaf örgütleri ve esnaf denetleme faaliyetlerinden hareketle üretici ve tüketici arasındaki uyuşmazlıkların çözümünde takip edilen çeşitli metotlardan bahsedilecektir.

Anahtar Kelimeler: İslam, Hukuk, Tüketici Hakları

* Yazar; çalışmanın hazırlanması esnasında bilimsel ve etik ilkelere uyulduğunu ve yararlanılan tüm kaynakların kaynakçada belirtildiğini, çalışmanın maddi açıdan fonlanmadığını, çıkar çatışması bulunmadığını beyan etmektedir.

** Dr. Öğr. Üyesi, Dokuz Eylül Üniversitesi İlahiyat Fakültesi, E-Posta: hadi.sofuoglu@deu.edu.tr, ORCID ID: https:/ / orcid.org / 0000-0001-5210-8257.

Makalenin Hakemlere Gönderiliş Tarihi : 06/12/2021

Makalenin Hakemlerden Geliş Tarihi : 23/12/2021 


\title{
CONSUMER RIGHTS AND MERCHANT CONTROL - EXAMPLES FROM OUR LAW HISTORY-
}

\begin{abstract}
Throughout history, the issue of consumer protection in the commercial life of societies is an issue that has never lost its currency. In this process, the main methods developed to protect the consumers, undoubtedly, are the issues of ensuring standardization and quality in production, measurement and weighing control, regulation and supervision of bazaars and markets. When we look at the sources of Islamic law, we see that the institution of options has been developed in order not to deceive consumers and to protect their rights. Since the early periods of Islam, a number of measures have been taken to protect consumers against defective goods and services, and consumers have been given the right to break the contract when faced with such a situation. From the time of the Prophet Muhammad to the present, there are also some institutions and organizations to resolve the disputes between the buyer and the seller, to guarantee the rights, and to protect the goods and service standards.

In this paper, legal measures regarding consumer and consumer rights throughout the history of Islam will be mentioned. In particular, examples will be given from various methods followed in the resolution of disputes between the producer and the consumer, based on the tradesmen organizations and tradesman inspection activities that we encounter in the Ottoman practice.
\end{abstract}

Keywords: Islam, Law, Consumer Rights

\section{GİRİŞ}

Bu çalışmada İslam hukuk tarihinde tüketici haklarını korumak için geliştirilen yöntemler ile çarşı-pazar ve esnaf denetlemeleri ile ilgili tespit ettiğimiz örnek şer'iye sicili kayıtlarından bahsedeceğiz. İslam hukukuna göre tüketici haklarını ortaya koyan kıymetli çalışmalardan ${ }^{1}$ faydalanarak hazırladığım bu tebliğ metninde Osmanlı kadısının

1 İslam Hukukuna gör tüketici haklarını konu edinen çalışmalar için Bkz. Alpaslan Alkış, İslam Hukuku Açısından Tüketicinin Korunması (Selçuk Üniversitesi Sosyal Bilimler Enstitüsü, 2012). Alkış, doktora tezinden hareketle konu ile ilgili bir makale daha yayınlamıștır. Alpaslan Alkıș, "İslam Hukukunda Tüketicinin Korunması", Kabramanmaras Sütçü Imam Üniversitesi Sosyal Bilimler Dergisi 16/1 (21 Nisan 2019), 73-138.Ahmet Nurullah Özdal, "Ortaçağ İslam Dünyasında Tüketici Grupları Ve Müşteri İlişkileri Üzerine”, Ağgr İbrabim Ceçen Üniversitesi Sosyal Bilimler Enstitiusü Dergisi 3/1 (25 Nisan 2017), 123-136; Mustafa Kisbet, "islam Hukukunda Ayıplı Mal Satışında Tüketicinin Korunması", İhya Uluslararası İslam Araștırmalar Dergisi 5/1 (05 Ocak 2019), 161-195. 
görevlerinde biri sayılan Pazar denetlemesi görevini ifa ederken tespit ettiği usulsüzlükleri ihtiva eden örnek birkaç belgeyi okuyucuların dikkatine sunmak istiyoruz.

Tüketici kavramı İslam hukuku kaynaklarında "müstehlik" şeklinde ifade edilmektedir. Müstehlik ise sözlükte, tüketen, helak eden, yok eden, bitiren, mal ve hizmetlerden yararlanan, satın alıp kullanan kişi gibi anlamlara gelir. ${ }^{2}$

İktisatç1lara göre tüketici, ekonomik değer taşıyan mal ve hizmetleri çeşitli ihtiyaçlarını karşılamak amacıyla satın alan kişi ya da kuruluşlardır. Buna göre, her türlü satın alma, bağışlama veya hibe etme gibi hangi sebeple veya yolla olursa olsun, mal ve hizmet edinen her özel veya tüzel kişi, tüketicidir. ${ }^{3}$

Modern Hukuk dilinde ise tüketici, bir mal veya hizmeti ticari veya mesleki olmayan amaçlarla satın alan, kullanan veya yararlanan gerçek ya da tüzel kişiyi ifade etmektedir. ${ }^{4}$ Buna göre tüketici bir mal veya hizmeti temin eden, kullanan ve tüketen son kullanıc1 demektir. Öte yandan bir mal veya hizmeti mesleğini icra etmek veya başka bir üretimin hammaddesi olarak kullanmak maksadıyla edinen kişiler tüketici sayılmamakta; sadece "Özel amaçlarla" satın alarak "nihai olarak" kullanan veya tüketen "gerçek veya tüzel kişiler" tüketici sayılmaktadır.

Tüketim ise sözlükte, yok etmek, üretilen şeyleri kullanmak, sarf etmek, harcamak, kullanarak bitirmek gibi anlamlara gelmektedir. Klasik İslam hukuku kaynaklarında da tanım buna uygun olarak yapılmıştır. Kaynaklarda tüketim kavramının karşıllğı olarak "istihlâk" mastarı ve bu

2 Ebû Bekr Şemsüleimme Muhammed b. Ahmed b. Sehl Serahsi, el-Mebsût (İstanbul: Çağr1 Yayınlar1, 1982), 11/105-106; 13/190; Alauddin Ebu Bekir b. Mes'ûd Kâsânî, Bedai'u's-sanâi' fî-tertîbi's-şerâi' (Daru'l-Kütübi'l-İlmiyye, 1986), 4/175; Kemalüddin es-Sivasi İbnü'l-Hümam, Fethu'l-kadir (Daru'l-fikr, ts.), 2/203.

3 Ahmed Tabakoğlu, İslâm ve Ekonomik Hayat (Ankara: Diyanet İşleri Başkanlı̆̆1 Yayınları, 1988), 43; Necat Berberoğlu, Temel İktisat Kavramlar ve Sorunları. Iktisada Giriş, II. Fasikeül (Eskişehir: Anadolu Üniversitesi Yayınları, 1989), 4-5.

4 Mehmet Bahtïyar - Levent Biçer, “Adi İş/ Ticari İş / Tüketici İşlemi Ayrımı ve Bu Ayrımın Önemi”, Marmara Üniversitesi Hukuk Fakültesi Hukuk Arastrmalar Dergisi 22/3 (16 Aralık 2016), 395-436.

5 Tüketicinin Korunması Hakkındaki Kanun, Md. 3. 
mastardan türetilmiş "istehleke" (tüketti) fiile kullanılmaktadır ve tüketmek, harcamak, dağıtıp bitirmek; helâk etmek, telef etmek, yok etmek, imha etmek, bitirmek gibi anlamlara gelmektedir.

İslâm, esas itibariyle meşru olan ürün ve hizmetlerin tüketimini yasal ve mubah kabul etmiştir. Zorunlu bir durum olmadikça zararlı, pis, gayrimeşru şeylerin tüketilmesi ise yasaklanmış, haram kılınmıştır. Meşru ve gayrimeşru ayrımının temelinden mal veya hizmetin yararlı veya zararlı olması yer almaktadır. Zira İslâm dini bütün iyi ve temiz maddelerin tüketimini serbest bırakırken pis ve zararlı maddelerin tüketimini ise yasaklamıştır.

Hz. Peygamber, tüketicilerin tüketim alışkanlıklarını düzene sokmak için çok önemli kriterler ortaya koymuştur. Bunlardan bazılarını şöyle sıralamak mümkündür. Tüketim faaliyetlerinin helal ve meşru zeminde yapılması gerekmektedir, ${ }^{6}$ haram ve gayrimeşru olan malların tüketilmesi yasaklanmıştır. ${ }^{7}$ Tüketim ve harcamalarda aşırılığa kaçılması hoş görülmemiş, ${ }^{8}$ gereksiz tüketim faaliyetlerinden uzak durarak tüketimde kibir göstergesi bulunmasin istenmiştir. ${ }^{9}$ Cimrilikten ve müsriflikten uzak bir şekilde makul ölçüler içinde cömert olunması tavsiye edilmiş, gereksiz ve ihtiyaç duyulmayan malların biriktirilip yığılmaması konusunda Müslümanlar uyarılmıştır. ${ }^{10}$ İsste bunlar tüketim için ortaya konmuş temel bazı esaslardır.

İslâm Hukukunun temel prensiplerine göre tüketiciyi hıyanetten korumak meşruttur. ${ }^{11}$ Yani tüketicinin korunması zorunluluk ifade etmektedir. Zira ekonomik ilişkilerde de hak ve adaletin tesis edilmesi ve insanların zarara sokulmaması İslâm'ın ortaya koyduğu en temel prensiplerindendir. Öte yandan İslam, tüketiciyi korumak için sadece hukuki kurallar koymakla yetinmemiş aynı zamanda ahlaki bir takım

\footnotetext{
Bubari (Beyrut: Darü’t-Te'sil, 2012), Büyû', 7.

Bubari, Büyû', 112.

8 Sabihu Müslim, ed. Neşr. Ebû Kuteybe Nazar Muhammed el-Fâryâbî (Riyad: Darü’tTalia, 2006), Eşribe, 67-68.

9 Müslim, Eşribe, 182-186.

10 Buhari, Libas, 1; Müslim, Zekat, 36.

11 Kâsânî, Bedâi, 5/366.
} 
erdemler üzerinde de oldukça fazla durmuştur. İnsanlar arasında adalet, doğruluk, kanaatkârlık, merhamet, sayg1, itidal... gibi ahlaki erdemlerin yerleşmesi için gayret gösterilmiştir. Çünkü ahlaktan yoksun bir hukuki uygulama her zaman adaletin tesisi için yeterli olmamaktadır.

Bu çalışmada İslam hukuk tarihi boyunca tüketicilerin haklarını korumak için ortaya konmuş hukuki tedbirlerden, yaptırımlardan, kurum ve kuruluşlar ile esnaf ve üreticilerin denetlenmesinden bahsedilecektir.

\section{2. İSLAM FIKHINDA ALIŞVERİ̧̧İN TEMEL PRENSÍPLERİ}

İslam alısverişe dair bazı temel prensipler ortaya koymuştur. Bu prensipler bugün bile geçerliliğini koruyan evrensel nitelikte prensiplerdir. Şimdi bu prensipler üzerinde durmak istiyoruz.

İlk ve genel prensip satilan maldaki kusurun gizlenmemesi prensibidir. Zira Hz. Peygamber "Kişinin malında bir kusur varsa, söylemeden satmas1 ona helal olmaz"12 diyerek maldaki kusuru gizlemek suretiyle yapılan hileli satışı yasaklamıştır. Satıştan sonra malın kusurunun ortaya çıkması halinde tüketici, İslâm fikhına göre muhayyerdir. Dilerse aldığ1 malı iade eder, dilerse kabul eder. ${ }^{13}$ Öte yandan satışını gerçekleştirmek için yalan yere yemin etmek de yasaklanmışır. Bu da çoğu zaman bir kusuru gizlemek veya malı olduğundan farklı göstermek için yapılmaktadır. Bir hadiste satıcıların müşterileri aldatıp mallarını daha yüksek fiyatla satmak için -vallabi bu mala senin verdiğinden fazlası verilmiştirşeklinde yalan yere yemin etmeleri üzerine “...Allab' a vermis olduğu sözllerini (abitlerini) ve yeminlerini az bir bedele satanlar var ya!. Isste onlar için abirette hiç bir nasip yoktur. Allah kryamet günü onlarla konusmaz, yüzlerine bakmaz ve onlar temize çkarmaz: Onlar için pek ackklı bir azap vardır" ${ }^{14}$ ayeti nazil olmuştur. ${ }^{15}$

12 Sünenüt-Tirmizi (thk. Muhammed Fuad Abdülbaki, Kahire: Mustafa el-Babi elHalebi, 1965), Büyû', 26.

13 Zeyla'î Ebû Muhammed Cemaleddin Abdullah b. Yusuf b. Muhammed, Nasbu'rRaye li Ehâdîsi'l-Hidâye (el-Mektebetü'l-İslâmiyye, 1973), 4/9.

14 Âl-i İmrân, 3/77.

15 Buhari, Büyû', 27. 
Bir diğer prensip, karaborsacıllğın (ihtikar) yasak olmasıdır. ${ }^{16}$ Karaborsacılık bildiğimiz üzere bir şeyi fiyatı yükselsin diye bekletmek, biriktirmek, hapsetmek, tedavülden çekmek, tek başına tasarrufta bulunmak için malı tekeline almak gibi anlamlara gelmektedir. İslam fikhında da aynı mana göze çarpmaktadır. İnsanların ihtiyaç duyduğu ticaret malını satın alarak, pahalılaşması gayesiyle istifleyip piyasaya arzını geciktirmektir ki bu yasaklanmışır. Hz. Peygamber bu tür iş yapan kimseleri lanetlemiş, günahkâr saymıştır. "Karaborsacı ne fena bir kuldur! Allah fiyatları ucuzlatırsa keyfi kaçar, yükseltirse çok mutlu olur" ${ }^{17}$ der.

Kur'an alışverişin karşılıklı rıza ile yapılmasını istemektedir. ${ }^{18} \mathrm{~Hz}$. Peygamber de alısverişte insanları serbest bırakmıştır. Bu noktadan hareketle İslâm'ın serbest piyasa ekonomisini benimsediğini söylemek mümkün olur ki mal ve hizmet bedellerinin serbest piyasa içinde kendiliğinden şekillenmesi bir prensip olarak konmuştur. Böylece fiyatlandırmanın değişik mahfillerden gelen baskılardan ve dış müdahalelerden uzak bir şekilde, serbest bir ortamda oluşması için bazı tedbirler ortaya konmuştur. Biraz önce de değindiğimiz gibi, insanların ihtiyaç duyduğu temel tüketim mallarını ucuza alıp saklayarak, daha sonra piyasada mal azaldığında bu malları pahalıya satmak yasaklanmıştır.

Hz. Peygamber, şehirlinin köylü adına satış yapmasını, pazara gelen köylüler ile uzak memleketlerden mal getiren yabanc1 tüccarların şehir dışında yolu kesilerek -onlar henüz pazarı ve oluşan fiyatları görmeden- mallarının şehir girişinde satın alınmasını yasaklamıștır. ${ }^{19}$ Yine mal veya hizmet fiyatlarının spekülatif hareketlerle suni olarak yükseltilmesi de yasaklanmıştır. Mesela, alıcı konumda olunmadığı halde bir mala gerçek değerinden yüksek fiyat vererek alışverişi kızıştırma, aralarında anlaşan iki kimsenin alışverişini daha fazla fiyat teklifi yaparak

16 Vehbe Zuhayli, “el-F1khu'l-İslami ve Edilletühü”, Şam: Dar Al-Fiker, 3/385.

17 Ebu Bekir Ahmed b. Hüseyin Beyhakî, es-Sünenül-kübrâ (Beyrut: Dârü’l-Kütübi’lİlmiyye, 2003), $7 / 525$.

18 Nisâ, 4/29.

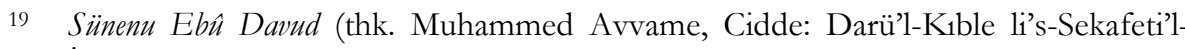
İslamiyye, 1998), Büyû', 65. 
arttırma da yasaklanmıştır. ${ }^{20}$ Doğal yollarla oluşan fiyatları narh koyarak sınırlamak İslam'ın temel alışveriş prensiplerine aykırıdır. Öte yandan spekülatif hareketler sonucu oluşan fiyatlara narh koymanın herhangi bir sakıncası olmadığını da burada belirtmemiz gerekir. Amaç alıcı ve satıcının serbest bir ortamda kendi rızaları ile buluşmalarını, mevcut malları gizleyip saklamadan veya olduğundan farklı göstermeden piyasaya arz edilmesini ve yine tarafların kendi rızaları ile alışveriş yapabilecekleri bir ortamın oluşmasını sağlamaktır.

\section{3. İSLAM FIKHINDA TÜKETİCIYYE TANINAN BAZI}

\section{HAKLAR}

Tüketici alışverişini yaptıktan sonra bazı hukuki düzenlemelerle korunmuştur. $\mathrm{Bu}$ düzenlemelerin başında muhayyerlik hakları gelmektedir. Muhayyerlik, Arapça "hayır" kökünden türetilmiştir ve "iki şeyden daha iyi olanı seçmek" manasına gelir. ${ }^{21}$ Fıkhi bir terim olarak, "anlaşmaya veya meşru bir gerekçeye dayanarak taraflardan birinin veya her ikisinin akdi onama yahut feshetme şıklarından birini seçme hakkına sahip olması" şeklinde genel bir tanım verilebilir. ${ }^{22}$ Klasik fikıh doktrininde şartlı muhayyerlikler ve hükmi muhayyerlikler olmak üzere genelde iki ana başlık altında ele alınır.

\section{1. Şarta Bağlı Muhayyerlikler}

Tarafların açıkça şart koşmasına bağlı olarak ortaya çıkan en temel muhayyerliklerdir. Bunlara iradî muhayyerlikler de denir. Bu tür muhayyerlik kendiliğinden ortaya çıkmaz, mutlaka akit esnasinda tarafların bu hakkı kullanmak istediğini beyan etmesi ve karşı tarafın da bunu kabul etmesi gerekir. Şarta bağlı muhayyerliklerden en meşhurları şunlardır:

20 Buhari, Buhari, Büyû', 60; Ebü'l-Velid Muhammed b. Ahmed b. Muhammed Kurtubi İbn Rüşd, Bidâyetü'l-müctehid ve nihayetü'l-muktesıd (thk. Abdülmecid Tu'me Halebi, Beyrut: Dâru'l-ma'rife, 1997), 2/273; Ebû Muhammed Muvaffakuddîn Abdullah b. Ahmed b. Muhammed İbn Kudâme, el-Muğnî (Dârü'l-Fikr, 1985), 4/148-149.

21 Ebu'l-Fadl Cemaluddin Muhammed İbn Manzûr, Lisânu'l-Arab (Beyrut: Daru'lSadr, 2011), H-Y-R Maddesi, 4/264.

22 Bkz. İbn Kudâme, el-Muğnî, 6/15. 


\subsection{1. Şart Muhayyerliği}

Alışveriş, kiralama gibi mal ve bedel değişimi esası üzerine kurulu, taraflarca feshedilebilir nitelikte ve bağlayıcı akitlerde tarafların mutabık kalmasına bağlı olarak birinin veya her ikisinin önceden belirlenmiş bir süre içerisinde akdi onama yahut feshetme yetkisine sahip olmasını ifade eder. ${ }^{23}$ Mecelle şart muhayyerliğini şu şekilde tarif etmiştir: "Bayi' ya müşteri veyahut ikisi birden müddet-i malûme içinde bey’ $i$ feshetmek yahut icazet ile infaz eylemek hususunda muhayyer olmak." 24 Mecelle'nin şart muhayyerliğini geniş şekilde kitâbu'l-büyû' kısmında ele almıştır. Bu durum klasik fikı kitapları sistematiğine uygun olmakla birlikte şart muhayyerliğinin sadece bey' akdine hasredilmesi diğer akitlerde geçersiz izlenimi uyandırmaktadır. Ancak şart muhayyerliği, bedellerin değişimi esası üzerine kurulu, feshi mümkün olan bütün akitlerde geçerli bir şart olarak ileri sürülebilir. ${ }^{25}$

Şart muhayyerliğinin bu hakkın sahibine akdi tek taraflı feshetme yetkisi verir. Günümüzde özellikle internet üzerinden yapılan alışverişlerde akit gerçekleştikten sonra, ürünün herhangi bir kusuru olmamasına rağmen,14 gün içinde müşterinin malı iade etme hakkı bu şart muhayyerliği ile ilgilidir.

\subsubsection{Tayin Muhayyerliği}

Tayin, Arapça “ayn” kelimesinden türemiş olup, "belirlemek, göz ile görüp tespit etmek" gibi anlamlara gelmektedir. ${ }^{26}$ Kyymeti veyahut özellikleri birbirinden farklı birkaç malın fiyatları ayrı ayrı belirtilerek, müssterinin bunlardan dilediğini alması veya satıcının dilediğini satması kaydıyla yapılan alışverişte taraflara tanınan seçim hakkıdır. ${ }^{27}$ Tayin muhayyerliği, müşterinin mallardan birini seçtiğini açıkça belirtmesi veya

23 Ömer Nasuhi Bilmen, Hukukı islâmiyye ve Istılahatı Fıkbiyye Kamusu (İstanbul: Bilmen Yayınevi, 1967), 6/55-56.

24 Mecelle Md. 300.

25 Recep Özdemir, "İslâm Hukukunda Şart Muhayyerliği”, İnönü Üniversitesi İlabiyat Fakültesi Dergisi 7/1 (03 Şubat 2017), 9.

26 İbn Manzûr, Lisânu'l-Arab, A-Y-N maddesi, 13/302.

27 Bilmen, Hukuku islâmiyye ve Istılahatı Fıkbiyye Kamusu, 6/64. 
mallardan birinde onu seçtiği anlamına gelecek bir tasarrufta bulunması ile sona erer. ${ }^{28}$

\subsubsection{Nakit Muhayyerliği}

Belirli süre içinde müşterinin ücreti ödememesi veya alışverişten sonra satıcının ücreti iade etmesi durumlarında satım akdinin gerçekleşmemesi üzerine kurulu bir muhayyerliktir. Şart muhayyerliğine benzer bir tarafı vardır. Ancak şart muhayyerliğinde süre dolduğunda akit kesinleşirken, nakit muhayyerliğinden süre sonunda akit batıl olur. ${ }^{29}$

\subsubsection{Ayıp Muhayyerliği}

Alışverişe konu olan maldaki kusurun satım akdinden sonra ortaya çıkması durumunda müşteriye malı iade etme hakkı veren bir muhayyerliktir. ${ }^{30}$ Taraflardan birinin alısverişten sonra, özellikle müşterinin satın aldığ1 malda değer düşürücü veya akitten beklenen fayday1 engelleyen bir kusur bulunduğunu fark etmesi üzerine akdi feshetme hakkına sahip olmasıdır. Ayıp muhayyerliği, işlerlik kazanmış olan akdi bağlayıcı olmaktan çıkarır ve bu hakkın sahibine tek taraflı olarak akdi feshetme yetkisi verir; bu takdirde malı iade ederek ödediği bedeli geri alır. ${ }^{31}$

\subsection{Hükmi Muhayyerlikler}

Hükmî olanlar, bireylerin şart koşmasına gerek duyulmadan meydana gelen ve akdin kendi yapısından yani akit gereği olarak oluşan muhayyerliklerdir.

\subsubsection{Rü'yet/Görme Muhayyerliği}

Müşterinin görmeksizin satın aldığı malı gördüğ̈̈nde akdi fesih hakkına sahip olmasıdır. ${ }^{32}$ Rü’yet muhayyerliği şart muhayyerliği gibi karşılıklı mal-ücret değişim esasına dayanan, fesh etmeye elverişli ve

28 Hasan Şahin, "İslam Borçlar Hukukunda Ta“yin Muhayyerliği”, Ondokuz Mayıs Üniversitesi İlabiyat Fakültesi Dergisi 45/45 (24 Aralık 2018), 12.

29 Bkz. H. Yunus Apaydın, "Muhayyerlik", Türkiye Diyanet Vakefi İslâm Ansiklopedisi, 1996, 31/28.

30 İbn Manzûr, Lisânu'l-Arab, A-Y-B Maddesi, 1/233.

31 Bkz. Apaydın, "Muhayyerlik", 31/28.

32 Serahsi, el-Mebsût, 13/69. 
tarafları bağlayıcı nitelikteki hukukî işlemlerde söz konusu olabilir. Ücretin peşin, malın veresiye olduğu selem akitlerinde zaten önceden bilinen, belirli bir şeyin özellikleri belirlenerek yapılan satımında ise görme muhayyerliği sabit olmaz. Malın önceden görülmüş olması muhayyerliği kaldırır. Ancak aradan malı müşteri açısından mâlûm olmaktan çıkaracak bir sürenin geçmesi halinde muhayyerlik hakkı doğar. Numune ile satılan şeylerde numunenin görülmesi satın alınacak malın görülmesi hükmündedir. ${ }^{33}$

\subsubsection{Meclis Muhayyerliği}

Tarafların akit yapılan meclisten bedenen ayrılmadıkları sürece kişisel iradeleriyle akitten vazgeçme hakkına sahip olmalarıdır. "Alıcı ve satıc1 ayrilmadıkları sürece muhayyerdirler" ${ }^{34}$ hadisi bu konuda delil olarak kullanılmaktadır. Alıcı veya satıcı satış sözleşmesinin yapıldı̆̆ı meclisi terk edinceye kadar sözleşmeyi tek taraflı feshetme yetkisine sahiptir. ${ }^{35}$

\section{4. İSLAM TARİHİNDE ESNAF DENETLEMELERİ}

İslâm hukuk tarihine baktığımızda tüketicilerin korunmasına yönelik ilk uygulamaları Hz. Peygamber dönemine kadar geri götürmek mümkündür. Zira kaynaklar bu konudaki birçok örnek hadiseyi onun yaşadığı dönemden günümüze aktarmaktadır. Sonraki dönemlerde de devam eden bu uygulamalar adeta günümüz tüketici hakları anlayışının da temellerini oluşturmaktadır.

İslâm'ın ilk dönemlerinden beri insanların alış-veriş hükümleri ve adabı konusunda bilinç sahibi olmaları için büyük çabalar gösterilmiş; alısverişin meşru ve gayrimeşru yönlerini bilmek büyük önem arz etmiştir. Mesela kaynaklarda bu bağlamda tüccarlar için Hz. Ömer’in "Dinde yeterli bilgisi olmayan çarşımıza girmesin. Ya da alış veriş ve faiz hakkında bilgisi yeterli olmayan çarşımıza girmesin" 36 dediği rivayet edilmiştir. Kısaca, alışveriş hukuku ile yeterli bilgisi olmayan kimselerin

\footnotetext{
Bkz. Apaydın, "Muhayyerlik”, 31/29.

Buhari, Büyû', 19.

Bkz. Apaydın, "Muhayyerlik”, 31/30.

Tirmizi, Vitr, 21.
} 
çarşı pazarda esnaflık yapmasına müsaade edilmemiştir. Kaynaklarda çarşı pazarlarda fiyat, kalite, düzen ve intizam denetlemeleri yapan ve aynı zamanda tacirleri hukuki kuralları bilip bilmemesi açısından da denetleyen kişilerden bahsedilmektedir. Bu kimselere "muhtesip"; bağlı bulundukları kuruluşun adına da "hisbe" teşkilatı denmektedir. ${ }^{37}$ Muhtesipler bir meslek dalında çalışan kimselerin ticaretle ile ilgili hükümleri yeterli düzeyde bilip bilmediğini sorguladığı, yeterli cevap alamazsa ticaretine izin vermediği kaynaklarda rivayet edilmektedir. Buradan anlaşıllyor ki tüketicinin korunmasında sadece tüketicinin bilinçlendirilmesi yetersiz kalmakta, aynı zamanda satıcının da eğitilmesi ve ticaret hükümleri konusunda bilgili olması gerekmektedir.

Muhtesipler çarşı ve pazarda malın kaliteli olup olmadığını da denetlemişlerdir. Zira Allah her şeyi en güzel bir şekilde yapmay1 emrettiğinden kaliteli mal ve hizmet üretimi İslâm'ın emirlerinden sayılmıştır. Konuyla ilgili Kur'an-1 Kerim'de Allah'ın sanatının iki ayrı yönüne vurgu yapılmaktadır. Bunlardan biri itkan, yani sağlamlık diğeri de ihsan, yani güzelliktir. ${ }^{38}$ Bir hadiste, "birisi bir iş yaptı̆̆ zaman Allah bunun sağlam ve yüksek vasıfta olmasından hoşlanır" ${ }^{39}$ buyurulmuştur. Bütün bunlardan hareketle üretilen mal ve hizmetlerin sağlam ve güzel olması İslam ticaret hukukunun başlica prensiplerindendir. Bu bağlamda hadislerde pazarda satılacak bir hayvanın sütünü birkaç gün sağmayıp memelerinde bırakarak yüksek verimliymiş gibi gösterilmesi yasaklanmıştır.

Hz. Peygamber zamanında üzerinde durulan konulardan biri de ölçü ve tartılarda belli bir standardın ortaya konulmasıdır. Zira alışverişte oluşabilecek haksızlığın önüne geçebilmek için ölçü ve tartıda belli bir standardizasyona gidilmesi gerekmektedir.

Kur'ân-1 Kerim'de konu ile ilgili olarak birçok ayet yer almaktadır. "Ölçüyü ve tartıyı adaletle tam yapın. İnsanların eşyalarını (mallarını ve haklarını) eksiltmeyin";40 “Ölçüyü ve tartıyı eksik yapmayın”; "Ölçüde

\footnotetext{
37 Cengiz Kallek, “Muhtesib”, Türkiye Diyanet Vakefi İslâm Ansiklopedisi, 1998, 18/143.

38 Neml, 27/88.

39 Ahmed b. Hüseyin Beyhakī, Şu'abü'l-imân, ed. M. Saîd b. Besyûnî Zağlûl (Beyrut, 1990), 4/334.

40 Hûd, $11 / 85$.
} 
ve tartıda hile yapanların vay hâline! Onlar insanlardan (bir şey) ölçüp aldıkları zaman, tam ölçerler. Fakat kendileri onlara bir şey ölçüp, yahut tartıp verdikleri zaman eksik ölçüp tartarlar" ${ }^{\text {"42 }}$ ayetlerini burada zikretmek mümkündür. Bu aytetlerde ölçü ve tartılarda hile yapılmaması, ölçümlerin âdil olarak yapılması ve insanlara haksızlıkta bulunulmamasını açıç̧a emredilmiştir. Ayrıca Kur'an, "Doğru tartın" "Doğru terazilerle tartın" diyerek ölçü ve tartının belli ve standart olması toplumun ticaret hayatındaki haksızlıkların önlenmesi için ne derece önemli olduğunu göstermektedir. Zira hicret öncesinde ve hicretten hemen sonraki dönemde ölçülerle ilgili sahtekârlıkta Medineliler'in çok ileride olduklarını gösteren rivayetler kaynaklarda yer almaktadır. Ne zaman ki Allah Teâlâ "Veylün li'l-mutaffifîn" ayetini indirince ölçüyü doğru yapmaya başlamışlardır. ${ }^{43}$

Hz. Peygamber hicretten sonra Medine'nin çarşı pazarına bir çeki düzen vermek istemiş, keyfi ve aldatıcı esnaf uygulamalarını ortadan kaldırmıştır. $\mathrm{Bu}$ amaçla piyasada kullanılan ve birbirinden farklılık gösteren ölçü ve tartılar arasında birliği temin etmek maksadiyla bir standart belirlemeye çalışmıştır ve "Ölçek Medine'nin ölçeği, tartı ise Mekke'nin tartısıdır" ${ }^{44}$ kuralını koymuştur. Piyasada kullanılan ve birbirinden farklllık gösteren diğer ölçüm aletlerini ve yöntemlerini kaldırmıştır. Doğru ve güvenilir ölçü ve tartılarla alışveriş yapılmasını istemiştir. Konuyla ilgili bir hadisinde "Sattı̆̆n zaman ölçerek sat, aldığın zaman da ölçerek al"; 45 diğerinde ise "Yiyeceklerinizi ölçünüz ki sizin için bereketli olsun" ${ }^{46}$ der. Böylece alışverişte kullanılan ölçü ve tartıların belli bir standartta olması ile oluşabilecek haksızlıkların önüne geçilmek istenmiştir.

Hz. Peygamber Medine'de sık sık esnaf denetlemesine çıkmıs, haksız kazanç sağlayan ve alışveriş kurallarını ihlal eden davranışlarda

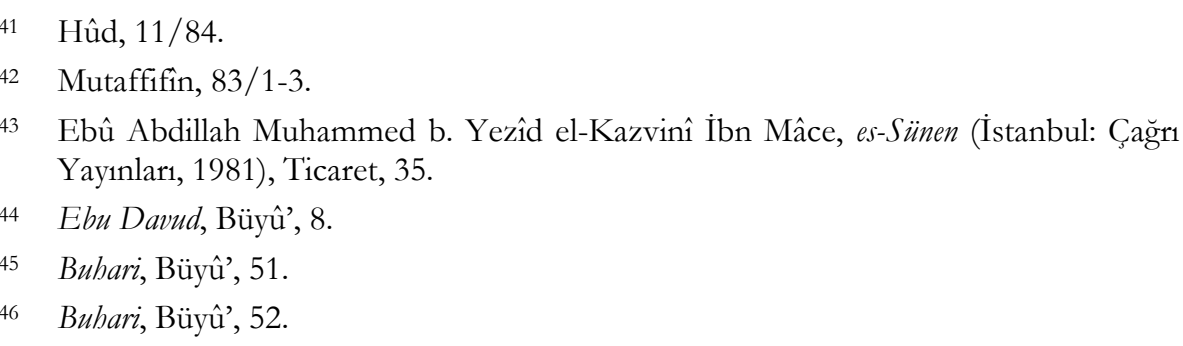


bulunanlara anında müdahale etmiş, gerekli tedbirleri uygulayarak özellikle esnaf sınıfina uyarı ve açıklamalarda bulunmuştur. Bir keresinde Hz. Peygamber pazarda "bir buğday satıcısının yanına gelmiş ve elini buğday çuvalının içine daldırdığında alt taraflarda bir 1slaklık hissetmiştir. Satıcıya 1slaklığ1 göstererek bu nedir diye sorduğunda satıcı, yağmurdan 1slandığını söylemiştir. Bunun üzerine, Hz. Peygamber, insanların görmesi için alt kısmını niçin üste getirmediğini sormuş ve "bizi aldatan bizden değildir," meşhur sözünü bu olay sonrasında söylemiştir. ${ }^{47}$

Hz. Peygamber çarşı ve pazar denetlemeleri için sahabeden bazı kişileri görevlendirmiştir. Abdullah b. Saîd ve Ömer b. el-Hattâb Medine pazarını denetleyen sahabilerdendir. Ayrıca Medine pazarını denetleyen ve dikkat çeken iki isim daha vardır ki bunlar kadındır. Hz. Peygamber bu hanım sahabileri çarşı-Pazar denetlemesi için görevlendirmiş, bu hanımlar da görevlerini hiç çekinmeden ve en iyi şekilde yerine getirmişler, hatta ellerinde değnek, kırbaç benzeri aletlerle olaylara müdahale ettikleri, anlaşmazlıkları giderdikleri rivayet edilmektedir. İşte bu iki meşhur hanım sahabiden birinin adı Semra bintu Nuheyk diğerinin adı ise Şifa binti Abdullah'tır. ${ }^{48}$

Hz. Peygamber'in vefatından sonra Raşit halifeler döneminde de çarşı ve pazarların denetimine titizlikle devam edilmiştir. Kaynaklarda Halifelerin bizzat bu denetimlere katıldıklarından bahsedilir. Mesela Hz. Ömer pazarları düzenli olarak denetlediği, Kur'ân'dan âyetler okuyarak alıcı ve satıcıları ikaz ettiği, çeşitli anlaşmazlıkları hükme bağlayıp esnafa gerekli uyarılarda bulunduğu ve yanlış yapanları cezalandırdığı nakledilir. Özellikle dışarıdan gelen yabancı esnafa: "Bizim pazarlarımızda ilgili hükümleri bilmeyenler ticaret yapamaz" diyerek uyarllarda bulunmuştur. ${ }^{49}$ Yine bir defasında Hz. Ömer'in minberde eline aldığ 1 "müd" ve "kist" adında iki ölçü aletini göstererek, bu ölçü ve tartılarda hile yapanlara, eksik ölçüp tartanlara beddua ettiği rivayet edilir. Hatta kullandıkları müdlerdeki eksiklik nedeniyle Yemenden gelen tüccarın

\footnotetext{
47 Müslim, İman, 164.

48 Muhammed Abdulhay b. Abdilkebîr b. Muhammed Kettânî, et-Terâtibü'l-Idâriyye: Hz.Peygamber'in Yönetiminde Sosyal Hayat ve Kurumlar, çev. Ahmet Özel (İstanbul: İz Yayınc1lik, ts.), 2/44.

49 Tirmizi, Vitr, 21.
} 
pazarda alışveriş yapmasını menetmiştir. Halkını da bu kişilerden alışveriş yapmasını yasaklamış, bu yasağı çiğneyen bir kişiyi de cezalandırmıştır. ${ }^{50}$

Aynı şekilde Hz. Ali'nin de düzenli aralıklarla çarşı-pazar denetimleri yaptığı, pazarcı sınıfina gerekli uyarılarda bulunduğu, yolunu şaşırana rehberlik ettiği belirtilir. Bu denetimler esnasında alışverişte yalan yere yemin edilmemesi gerektiğini, farklı cinsten malların birbirine karıştırılmamasını, tazeliğini kaybetmiş ürünlerin, bayatlamış balıkların satılmaması gerektiğini belirtmiştir.

Daha sonraki dönemlerde de üretim ve hizmette standardizasyon ve kaliteye büyük önem verilmiştir. Özellikle Osmanlı Devleti döneminde "Bursa, Edirne, Sivas, Konya, Diyarbakır, Çankırı, Aydın, Mardin, Karahisar, Musul, Rize, Amasya, İçel, Arapkir, Karaman ve emsali yerlerin" mahalli özelliklerine ve üretim çeşitlerine göre standart kurallar konulmuş ve ciddi şekilde uygulanmıstır. Bunlardan ferman olarak en eskisi II. Bayazıd'ın yürürlüğe koyduğu 907/1502 tarihinde "Kanuname-i İhtisab-1 Bursa"dır. ${ }^{51} \mathrm{Bu}$ ferman, standardın bugünkü anlamında kavrandığını gösteren yazılı en eski belge olarak Dünya tarihîne geçmiştir. Bu belgede kalite, boyut, ambalaj gibi konularda standardlar tespit edilmiş, narh ve ceza hükümlerine yer verilmiştir. Kanun metnine konulmuş olan hükümler, devrin bir nev'i standart kanunu niteliğindedir.

Osmanlı Devletinde yürürlükte olan İhtisap Kanunlarında pazar denetçisi muhtesibin görevleri belirtilmiştir. Bunlar ölçü ve tartı ayarlarının kontrol edilmesi, ayarı bozuk ölçü ve tartı aletleri ile hile yapılmasına engel olunması, eksik ölçüp tartanlara veya eksik dirhem kullananlara çeşitli mali cezaların verilmesidir. Osmanlı Dönemi Şer’iyye Sicilleri, yapılan kontroller sırasında gramaj eksikliği tespit edilen mallara ve sahiplerine ilişkin olarak tutulmuş kayıtları da ihtiva etmektedir.

Şer'iye sicili defterlerinde kadı veya muhtesiplerin yaptığı çarşıpazar ve esnaf denetimleri ile ilgili kayıtlara rastlamak mümkündür. Şimdi burada söz konusu kayıtlardan birkaçını zikredip değerlendirmesini

50 Bkz. Alkış, İslâm Hukuku Açısından Tüketicinin Korunması, 106.

51 Recep Özdemir, "Tüketici Haklarına Yönelik Tarihte Yapılan İlk Kanun: 'Kanunname-i İhtisab-1 Bursa”, Mecmua 4 (31 Aralık 2017), Bkz. 
yapmak istiyoruz. Bunlardan ilki 1640 yılına ait 65 nolu Manisa Kadılığına ait şer'iye sicili defterinden:

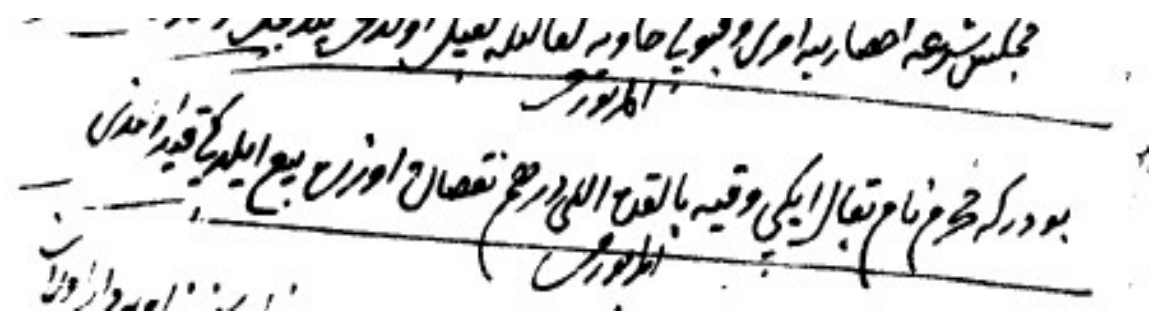

"Budur ki, Muharrem nâm bakekâl iki vukayye balıkta elli dirhem noksan üzere bey' ettiği kaydolundu."

Vukıyye 400 dirhemlik bir tartı birimidir. Bir dirhemin bugünkü karşılığı yaklaşık 3,2 gramdır. ${ }^{52}$ Buna göre bir vukıyye $1280 \mathrm{gr}$, iki vukıyye de yaklaşık 2,5 kg yapmaktadır. Bakkalın balıkları satarken kullandığ1 vukıyyelerin 25'er dirhem noksan olduğuna göre bakkal $2,5 \mathrm{~kg}$ balık yerine 160 gr eksikle $2.34 \mathrm{~kg}$ balık satmaktadır. Bu da denetlemeye takılmış ve durum sicil defterine bu şekilde kaydedilmiştir.

Yine aynı defterden başka bir denetleme örneği:

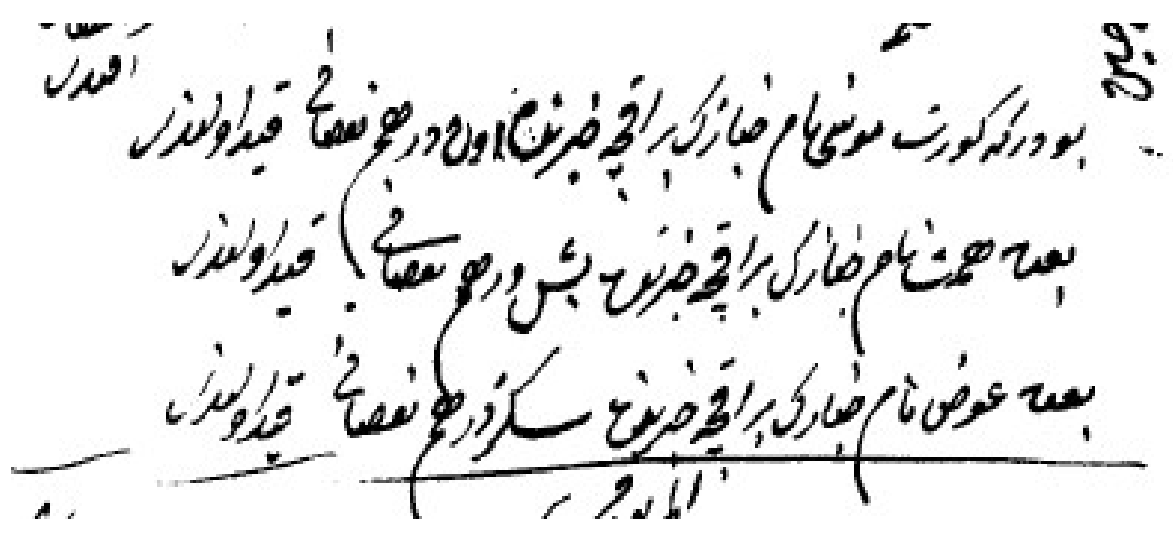

52 Cengiz Kallek, "Ukıyye", Türkiye Diyanet Vakfi İslâm Ansiklopedisi, 2012, 42/67. 
Belgeden anlaşıldığına göre Kadı ve beraberindeki heyet firınları denetlemeye çımış, tespit ettikleri eksiklikleri sicile şu şekilde kaydetmişler.

1. Satır: Budur ki Kürt Musa nâm habbažn bir akçe bubzunda on dirbem noksanı kaydolundu.

Fırında satılan bir akçelik ekmeğin on dirhem eksik tartı ile satıldığ1 tespit edilmiştir. Günümüz ölçü birimlerine göre 1 dirhem yaklaşık 3,2 gr gelmektedir. Dolayısıyla satılan ekmek 32 gr eksik gramajlidir.

2. Satır: Ba'dehu Himmet nâm habbaz̨n bir akçe bub₹unda beş dirbem noksan kaydolundu

Fırıncı Himmet'in bir akçelik ekmeği beş dirhem noksan tartı ile sattığ1 tespit edilmiş, günümüz ölçü birimleri ile ifade edecek olursak 16 gr eksiklik söz konusudur.)

3. Satır: Ba'dehu Ivaz, nâm babbazın bir akçe bubzunda sekiz dirbem noksan kaydolundu.

Fırıncı Ivaz'ın da aynı şekilde bir akçelik ekmeği sekiz dirhem eksik tartarak sattığ tespit edilmiş ve bu durum sicile kaydedilmiştir. )

Bazen daha önce kendilerine yapılan uyarıları dikkate almayarak eksik tartı ile satış yapmaya devam eden esnafın kalabentlikle cezalandırıldığını görüyoruz. Nitekim 1741 tarihli Eyüp Mahkemesi sicil kaydına göre Çörekçi İbrahim firınında kullandığı dirhemlerden 100 dirhem ağırlıkların 70 dirhem, 50 dirhem ağırlıkların da 35 dirhem geldiği tespit edilmiştir. Çörekçi İbrahim daha önce eksik tartı kullanması nedeniyle uyarılmasına rağmen hala aynı şekilde tartılarında eksiklik tespit edilince başkalarına ibret olsun diye kalabentlikle cezalandırılmıştır. 


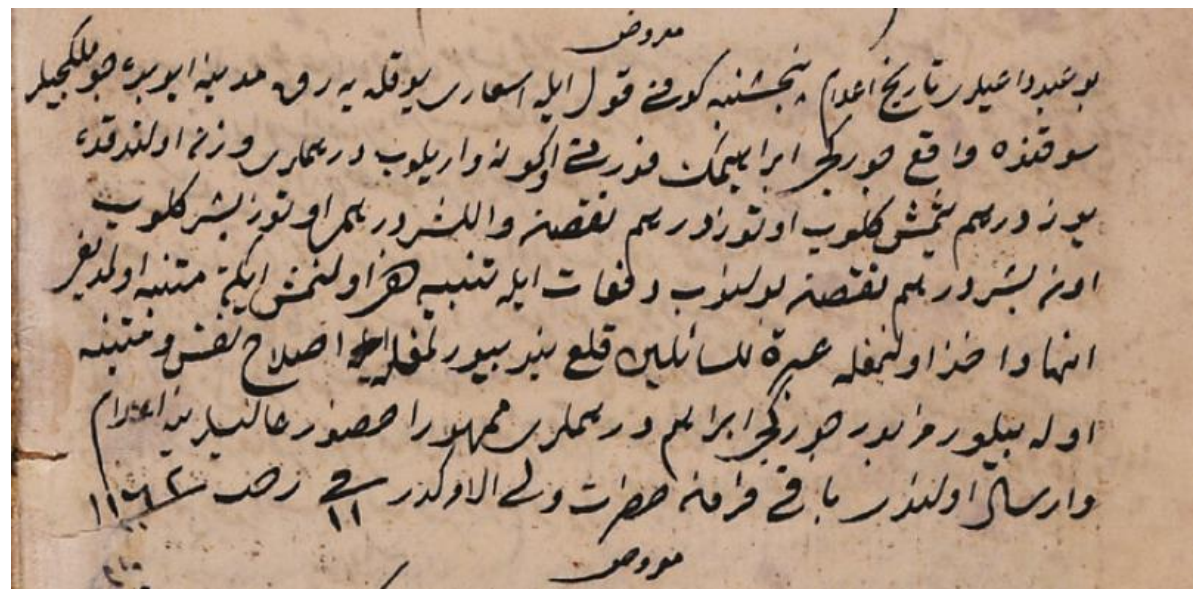

"Bu abd-i dâ'îleri târîh-i i lâm Perşembe günü kavl ile es 'âr yoklayarak medîne-i Eyüb'de çömlekciler sûkunda vâki' Cörekci İbrahim'in firm önüne varlip dirhemleri vezn olundukda yüz dirhem yemis gelip otuz dirhem noksan ve elliser dirbemi otuabeşer gelip on beşer dirhem noksan bulunup defâ'at ile tenbîh dabi olunmus iken mütenebbih olmadiğr inhâ ve abz olunmağla ibretü'l-li's-sâ'irîn kal'abend buyrulmağla uslâh-ı nefs ve mütenebbih olabilir mezbûr Cörekeci İbrabim

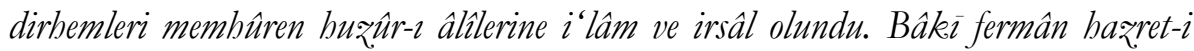
veliyyü'l-emrindir."

\section{DEĞERLENDİRME VE SONUÇ}

Hukuk tarihimize baktığımızda çarşı pazarın düzenini sağlamak ve tüketiciyi korumak için birçok hukuki tedbirin alındığını görüyoruz. Tüketicilerin korunmasina yönelik ilk uygulamaları Hz. Peygamber dönemine kadar geri götürmek mümkündür. Hz. Peygamber zamanından beri idareciler esnafin cari ticaret hukuku kurallarına göre ticaret yapıp yapmadıklarını denetlemişlerdir. Kaynaklar bu konudaki birçok örnek hadiseyi onun yaşadığ1 dönemden günümüze aktarmaktadır. Sonraki dönemlerde de devam eden bu uygulamalar adeta günümüz tüketici hakları anlayışının da temellerini oluşturmaktadır.

Çarşı pazarlarda fiyat, kalite, düzen ve intizam denetlemeleri yapan ve aynı zamanda tacirleri hukuki kuralları bilip bilmemesi açısından da denetleyen hisbe teşkilatının kurulduğunu görüyoruz. Bu teşkilat mensuplarına "muhtesip" denmektedir. Muhtesipler bir meslek dalında çalışan kimselerin ticaretle ile ilgili hükümleri yeterli düzeyde bilip bilmediğini sorgulamakta; yeterli cevap alamazsa ticaretine izin 
vermemektedir. Muhtesipler denetimlerde bir taraftan satılan ürünlerin ve hizmetlerin belli standartları sağlayıp sağlamadığı hususlarına dikkat ederken diğer taraftan ölçü ve tartı aletlerinin eksik tartıp tartmadığını da kontrol etmişlerdir.

Muhtesiplerin denetleme esnasinda tespit ettikleri usulsüzleri kadı defterlerine kaydedilmesini sağlamışlardır. Şer’iye sicili defterleri söz konusu denetimlere ilişkin kıymetli bilgileri günümüze aktarmaktadır.

Öte yandan İslâm'ın ilk dönemlerinden beri insanların alış-veriş hükümleri ve adabı konusunda bilinç sahibi olmaları için büyük çabalar gösterilmiş; alışverişin meşru ve gayrimeşru yönlerini bilmek büyük önem arz etmiştir. Bundan dolayı alşveriş hükümlerini bilmenin üzerinde esnaf-lonca teşkilatlanında hassasiyetle durulmuştur. 


\section{KAYNAKÇA}

Alkış, Alpaslan. "İslâm Hukuku Açısından Tüketicinin Korunması". Selçuk Üniversitesi Sosyal Bilimler Enstitüsü, 2012.

Alkış, Alpaslan. "İslam Hukukunda Tüketicinin Korunması". Kahramanmaraş Sütçü Imam Üniversitesi Sosyal Bilimler Dergisi 16/1 (21 Nisan 2019), 73-138.

Apaydın, H. Yunus. "Muhayyerlik". Türkiye Diyanet Vakefi İslâm Ansiklopedisi, 1996.

Bahtïyar, Mehmet - Biçer, Levent. “Adi İş/ Ticari İş / Tüketici İşlemi Ayrımı ve Bu Ayrımın Önemi”. Marmara Üniversitesi Hukuk Fakültesi Hukuk Arasstrmalarn Dergisi 22/3 (16 Aralık 2016), 395436.

Berberoğlu, Necat. Temel İktisat Kavramlar ve Sorunlar. İktisada Giriş, II. Fasikül. Eskişehir: Anadolu Üniversitesi Yayınları, 1989.

Beyhakī, Ahmed b. Hüseyin. Şu 'abü'l-îmân. ed. M. Saîd b. Besyûnî Zağlûl. Beyrut, 1990.

Beyhakî, Ebu Bekir Ahmed b. Hüseyin. es-Sünenü'l-kübrâ. Beyrut: Dârü'lKütübi'l-İlmiyye, 2003.

Bilmen, Ömer Nasuhi. Hukuke islâmiyye ve Istılahatı Fıkbiyye Kamusu. İstanbul: Bilmen Yayınevi, 1967.

Buhari, Ebu Abdullah Muhammed b. İsmail b. İbrâhîm el-Cu’fî 256/870. Buhari. Beyrut: Darü't-Te'sil, 2012.

Ebû Davud es-Sicistani, Süleyman b. Eş'as b. İshak el-Ezdi. Sünenu Eb̂ิ Davud. Thk. Muhammed Avvame. Cidde: Darü'l-Kıble li'sSekafeti'l-İslamiyye, 1998.

Ebû Muhammed Cemaleddin Abdullah b. Yusuf b. Muhammed, Zeyla'̂̂. Nasbu'r-Raye li Ebâdîsi'l-Hidâye. el-Mektebetü'l-İslâmiyye, 1973.

İbn Kudâme, Ebû Muhammed Muvaffakuddîn Abdullah b. Ahmed b. Muhammed. el-Muğnî. Dârü’l-Fikr, 1985.

İbn Mâce, Ebû Abdillah Muhammed b. Yezîd el-Kazvinî. es-Sünen. İstanbul: Çağrı Yayınları, 1981. 
İbn Manzûr, Ebu'l-Fadl Cemaluddin Muhammed. Lisânu'l-Arab. Beyrut: Daru'l-Sadr, 2011.

İbn Rüşd, Ebü'l-Velid Muhammed b. Ahmed b. Muhammed Kurtubi. Bidâyetül-müctebid ve nibayetül-muktesid. Thk. Abdülmecid Tu'me Halebi. Beyrut: Dâru’l-ma'rife, 1997.

İbnül-Hümam, Kemalüddin es-Sivasi. Fethu'l-kadir. Daru'l-fikr, ts.

Kallek, Cengiz. "Muhtesib". Türkiye Diyanet Vakfi İlâm Ansiklopedisi, 1998.

Kallek, Cengiz. "Ukıyye”. Türkiye Diyanet Vakfi İlâm Ansiklopedisi, 2012.

Kâsânî, Alauddin Ebu Bekir b. Mes'ûd. Bedai'u's-sanâi' fî̀-tertîbi'ş-şserâi'. Daru'l-Kütübi'l-İlmiyye, 1986.

Kettânî, Muhammed Abdulhay b. Abdilkebîr b. Muhammed. et-Terâtibü'lİâriyye: Hz:Peygamberin Yönetiminde Sosyal Hayat ve Kurumlar. çev. Ahmet Özel. İstanbul: İz Yayıncilık, ts.

Kisbet, Mustafa. "islam Hukukunda Ayıplı Mal Satışında Tüketicinin Korunması". İhya Uluslararasi Islam Araştrrmalar Dergisi 5/1 (05 Ocak 2019), 161-195.

Müslim, Ebü'l-Hüseyin el-Kuşeyri en-Nisaburi. Sabibu Müslim. ed. Neşr. Ebû Kuteybe Nazar Muhammed el-Fâryâbî. Riyad: Darü't-Talia, 2006.

Özdal, Ahmet Nurullah. "Ortaçağ İslam Dünyasında Tüketici Grupları Ve Müssteri İlişkileri Üzerine”. A ̈grn İbrabim Cegenen Üniversitesi Sosyal Bilimler Enstitüsü Dergisi 3/1 (25 Nisan 2017), 123-136.

Özdemir, Recep. "İslâm Hukukunda Şart Muhayyerliği”. İnönü Üniversitesi Ilabiyat Fakültesi Dergisi $7 / 1$ (03 Şubat 2017), 139-172.

Özdemir, Recep. “Tüketici Haklanna Yönelik Tarihte Yapılan İlk Kanun: 'Kanunname-i İhtisab-1 Bursa”. Mecmua 4 (31 Aralık 2017), 1-16. https://dergipark.org.tr/tr/pub/mecmua/350962

Şahin, Hasan. "İslam Borçlar Hukukunda Ta'yin Muhayyerliği”. Ondokur. Mayıs Üniversitesi İlabiyat Fakültesi Dergisi 45/45 (24 Aralık 2018), 183-208. 
Serahsi, Ebû Bekr Şemsüleimme Muhammed b. Ahmed b. Sehl. elMebsût. İstanbul: Çağrı Yayınları, 1982.

Tabakoğlu, Ahmed. İslâm ve Ekonomike Hayat. Ankara: Diyanet İşleri Başkanlığ1 Yayınları, 1988.

Tirmizi, Ebû İsa Muhammed b. İsa b. Sevre es-Sülemi. Sünenü’tTirmizi. Thk. Muhammed Fuad Abdülbaki. Kahire: Mustafa el-Babi elHalebi, 1965.

Zuhayli, Vehbe. “el-F1khu'l-İslami ve Edilletühü”. Şam: Dar Al-Fiker, 1997. 